\title{
VALIDITY AND TIME OF CONTRACTUAL OBLIGATIONS ARISING FROM COMPENSATION IN IRAN AND BRITISH LAW
}

\author{
Ali Asghar Kargar ${ }^{1}$ \\ Mozafar Bashokouh ${ }^{2}$ \\ Mansour Eshghpour ${ }^{3}$
}

\begin{abstract}
Three ways to enforce the same obligation are to terminate and pay damages in respect of the guarantee of contravening contractual obligations in common legal systems, although the primacy of these compensatory methods varies from one to another in each system. In England, four types of damages are foreseen for breach of contractual obligations: compensatory or remedial damages, recovery or restitution, nominal damages, and punitive damages. Recovery damage is assessed with two predicted damages and repossessing damages. The moral damage is also in the category of compensatory damages, but it has its own rules. In Iranian law, the law expresses some conditions, barriers, and forms of damages. Items such as loss, existence of causality, certainty, predictability, and directness as other
\end{abstract} conditions involved in creating the right to claim damages are raised by legal theory. Applied issues such as the compensation criteria are also not a specific place in the legal system of Iran. Limitations on damages, including unlikeness, discounting theory, the involvement of the injured party in Cairo's rights in England, have been developed to identify each of the criteria and criteria for evaluation; in the Iranian legal system, Cairo's power is explicitly stated in the law. And other cases have been raised more and more in legal theory. The incomplete and disproportionate expression of the rules governing the compensation of Iranian law as well as the necessity of achieving a comprehensive military system in this regard, taking advantage of the theoretical and practical experience of the English law, is an essential

\footnotetext{
${ }^{1}$ Department of Law, Germi Branch, Islamic Azad University, Germi, Iran

${ }^{2}$ Department of Law, Ardabil Branch, Islamic Azad University, Ardabil, Iran. *Corresponding Author Email: m.bashokouh39@gmail.com.

${ }^{3}$ Department of Law, Germi Branch, Islamic Azad University, Germi, Iran.
} 
requirement for the present study.

Keywords: Compensation, Contract Violation, Compensatory Damage, Expected Damage, Retirement Damage

\section{Introduction}

Commitment is a legal relationship whereby a person is required to transfer and surrender property or work or refrain from doing anything else. In contractual obligations, the rule of will is accepted as a principle and is based on the legal obligations of the basis of the obligation, rule of law, and "misplacedness". The impossibility of fulfilling the obligation may be due to the law, and if the impossibility of implementation is temporary or exists between the commitment and execution time and then resolved, it will not lead to the cessation of the commitment. Ensuring commitment to fulfill obligations is one of the factors convincing individuals to conclude a contract because, according to the wisdom and rationale of the intellect, the person who does not trust the adherence to the commitment to the contract does not conclude a contract. Even in the assumption of doubt, the wisdom rules that when it concludes a contract, it is committed to comply with the obligations of the contract of guarantee.

The contract is a credit that is created on the will of both parties. This has led to an analysis of this phenomenon not so easy. Because the creative will of the parties is not the only source of analysis of the contract, there are also requirements for lawmakers and legal principles that indicate the conditions for the validation of legal practice. There is no doubt that the custom in regulating legal relations is not dependent on the analysis of lawyers and is based on his own needs. Accordingly, the study of the role of the committed person in the validity and execution of the contract is not a forbearance and it usually happens. Therefore, it was necessary to evaluate its nature and validity by analyzing what happens in the custom and its application to the principles and rules of law.

One of the main conditions that the legislator has for the parties to the contract and the subject of discussion in this study is the ability to commit this feature both during the stage of contracting and in the implementation phase, and maybe in the absence of the 
contract Canceled Given the fact that the contracts are voluntary agreements between individuals and non-financial affairs, the authorities consider the principle of the correctness and implementation of the contracts in terms of the support of contractors. Individuals could contract and contract, in addition to general publicity for the implementation of contracts, have a specific occupation due to the nature of the contract or transaction. In other words, the obligation to be bound by the obligation must be a kind of connection and affiliation, because Pledged

It is committed to the commitment and is committed to fulfilling its obligation, not its own ability.

Although in the general rules of contracts and in the context of the contracting terms, the ability to commit as one of the components of the validity of the contract is not mentioned, however, its value is less than some of the conditions mentioned in Article 190 of the Civil Code. The significance of the issue appears where the commitment of the obligated party is stipulated in the contract or the committed character of the obligated party is of great importance and, on the other hand, since, whenever a person undertakes, he implicitly exercises his power and ability Confesses to its implementation, and if the committed pledge is also willing to pay, it is, of course, implicit on the basis of this confession, and therefore, if after the conclusion of the contract in such a manner the ability to commit to the implementation of the problem encounters, it may be shaken in The origin of the obligation is to question the validity of the agreement in terms of doubt in principle.

\section{The basis and the precise contractual obligations}

Commitment is a legal relationship whereby a person is obliged to transfer and surrender property or work or to refrain from doing any work, whether it is an agreement or an obligation or a voluntary obligation. Commitment has two basic pillars: the subject matter of the commitment and the parties to the commitment. The subject of the obligation must be certain, has a tax, can be surrendered and is not false. It is not possible to imagine a commitment without commitment and commitment, since it must be determined who is committed to whom it is required 
to perform the obligation, and when these two traits (dying and mediation) are accumulated in one person, the obligation is void (Amir Mo'azi, 1391, $65)$.

\section{-The attributes of commitment are:}

1- Commitment is a legal relationship that arises between individuals and is relative.

2- Commitment is mandatory and binding.

2. Commitment means a specific financial commitment, although commitment to its general concept encompasses all human relationships, but in a specific sense, it is obligatory to refer to the transfer of property or the performance of a business involving a financial relationship.

\subsection{The boundaries of committed} commitment and determination of the affected party.

The bounds of committed commitment are considered to be a standard impediment, that is, in the event of an accident, the ability of a normal person to be considered and applied accordingly. Therefore, according to
Articles 224 and 225 of the Civil Code, the appropriate criterion is conventional human power and the impossibility of executing a contract, the original source of the exemption owes its commitment to duty and responsibility, and shows that the owed is not entitled to punishment and has not committed a fault. With the incident and the impossibility of the implementation of the contract, the obligations arising out of the contract are eliminated, and the result of this is the exclusion of each of the two sides against the other, and it can be said that it is committed in losses in the contract and committed in an unconditional contract to the detriment of the pledge, The existence of a contract intrinsically means the elimination of the obligation and their dependence, since each of the voters is a different cause, except for the cases specified by the law. In contracts the subject of which is an action or a certain gain, the obligation of the other party is canceled by the impossibility of fulfilling the obligations of each party, because the nature of the contract is subject to the necessity of this action, and whenever the subject of the contract is the same, Submission is due to property (Kazemnezhad, 2010, 49). 


\subsection{Conditions relating to the subject of the contract}

A contract is enforceable in which the property or object is of a qualitative nature. This description can be summarized as follows:

The subject matter of the contract must be available at the time of the contract, it is transferable, specified and specified, can be surrendered and surrendered, and finally the transferor must be responsible. Now we examine each of these cases (Babaei, 2007, 79):

A) Availability at the time of the contract: When the subject of the contract is the transfer of the property, if this property is something specific or socalled "definite", it must be available at the time of the contract. Otherwise the contract will be null and void. It is not necessary to observe this condition for things that are general.

B) Taxation: The purpose of taxation is that the subject of the contract should be economic exchange. The subject of the contract may be tax-exclusive to the parties to the contract and considered to be non-taxable for others.

C) Transferability: the subject of the contract must be legally (and lawfully)
362

transmitted, then the purchase and sale of the materials, The drug or alcoholic beverage or weapons (except in authorized cases) or prohibited books or urban land (except in the cases specified in the law) as the subject of the contract. E) It is known and certain: the subject matter of the contract must be "determined" in terms of gender and quantity, and the contract subject should not be one of several things without "determination".

C) Ability to Submission and Submission: Time can be used to finance the subject of the contract, so that the property can be surrendered to the other. This capability may be due to its ability and power to surrender. This attribute must be searched in each item according to the existing and existing custom and the characteristics and characteristics of each specific commitment.

(Iv) The carrier's role: the person who transfers something to someone should have the necessary authority to do so. It means either owning or owning the owner.

\section{Damages caused by non-fulfillment of obligations and methods of dealing with it}




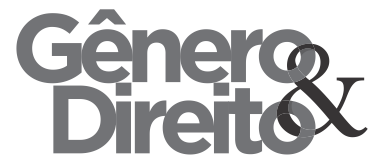

Periódico do Núcleo de Estudos e Pesquisas sobre Gênero e Direito

Centro de Ciências Jurídicas - Universidade Federal da Paraíba

V. 8 - $\mathrm{N}^{\circ} 03$ - Ano 2019

ISSN | 2179-7137 | http://periodicos.ufpb.br/ojs2/index.php/ged/index
When it undertakes to refrain from fulfilling its obligations, two issues are raised, one is the issue of fulfilling the principle of obligation, the other is the issue of compensation for failure to perform or delay in fulfilling the obligation. For these two problems, various solutions can be predicted in the contract (Isanlou, 2011, 55):

Firstly: To do the matter on behalf of the pledged party:

In this case, the sponsor undertakes to fulfill the obligation and pledges the cost of this action. Obviously, in this case, the committed person will not be offended by the thought of saving and respecting envy.

Second: Daily Damage Determination:

The contract stipulates that any delay in the execution of the contract or delay in delivery will be paid.

Third: Determining daily damages and committing to committed costs:

This is the sum of the two previous modes. For example: "If the other party refuses to execute the contract, the first party may, at the expense of the other party, decide on the implementation of the terms of the contract. Make Meanwhile, the second party is obliged to pay one million Rials to the first for each day of delay.

Fourthly: payment of fixed-term loss (obligation):

In this case, a certain amount is paid for damages to the obligee. This payment, as the case may be, may become a commitment or not.

- Khamsa: How to compensate if the subject of the commitment is cash.

If a commitment position is a cash payment, there are a number of ways to predict the contract:

A. If the item is intended to be returned to the installment, it can be stipulated that, in case of delay in payment of each installment, the remaining installments will be available and the unit payment will be demanded.

B. Delayed payment can be predicted for late payment. 
For example: "If the debtor fails

to pay his debt on the due date, the delay in damages to the source ...\% (percent) per annum will be based on Article 522 of the Civil Procedure Law. This loss continues until the principal debt is paid, even if its amount exceeds the total amount of religion. "

\section{Crash of obligations in the contract}

1. Sediment: The most basic form of a commitment is to fulfill an obligation or to undertake a commitment, provided both the commitment and the commitment are agreed upon and subject to the commitment of the amount and nature of the commitment.

2. Excerpts: Excuses or Excuses are the agreement and mutual agreement between the parties on the dissolution of the concedes previously concluded.

3. Obra: Article 289 of the Civil Code deals with the definition of the term: the term is to deny the creditor a right to the discretion. Abraa is one of the legal acts, that is, a legal situation which is obtained by one's will or will and does not require the acceptance of the other party. The term is meant to be free of charge or to be released, and the power provided for in Article 289 of the Civil Code expresses this It is not imperative to forcefully and reluctantly.

4. Conversion of a commitment: Article 292 of the Civil Code regarding the conversion of obligations states: "The conversion of a commitment shall be made in the following cases: 1 . When committed and committed to transforming the main obligation into a new commitment that becomes its vice president, In this case, committed to the original commitment. 2- When a third party agrees to consent to the committed deed. 3- When it comes to transferring someone else's commitment to the committed mafia.

5. Tahrat: A truce is a two-tiered request from two creditor who are placed opposite each other. In other words, it is easier to prevent repetition of religion. Fighting or acting on religion is a general rule of law, whether it is intentional or contractual or judicial. The most important and commonly used material in the community is the money launderer among banks in bank lending. The purse in each bank is referred to as the Cleaning House.

6. We Own Property: Article 300 of the Civil Code provides for our property: If we are indebted to our ownership of our 
property, it will be deductible. Our property at the time is to create a legal status that a person owes, Is the owner of his debt and is one of the causes of the collapse of his obligations (Hossein Ebadi, 2009, 37).

\section{The basis for the agreement for} damages and the terms of eligibility for the agreed loss

According to Article 230, the settlement fee is the amount that both parties to a contract (which is not a principal obligation to pay cash) during their contractual negotiations as a definitive damages suffered as a result of the violation of the other party, and in a manner inconsistent with the law Not included in the contract. The remarkable point is that the amount of "contractual obligation" should be determined by the "legal obligation", which the court determines in the course of resolving the dispute between the parties for delinquency in the performance of a commitment that is not fulfilled by the obligee except by the obligated party and can be reduced or increased, and "Noncontractual liability", which the law specifies in certain cases (Bahrami, 2007, p. 29).

\subsection{Failure to fulfill obligations}

The primary purpose of the parties is to conclude any contract, and it is not a real alternative to it. Consequently, disputes must always be the subject of an application for enforcement.

\section{Failure to fulfill obligations}

The primary purpose of the parties is to conclude any contract, and it is not a real alternative to it. As a result, disputes must always be the subject of an application for enforcement and, if not, demand for damages. In some contracts, the time of execution of the contract is an important factor, and the violation of the law enforces at the time that the obligated party no longer wishes to enforce it out of time. This is the only way to replace his compensation. But in other times, despite the passage of time, the contractor is still committed by the contractor. Whether, after such a situation, the obligee can ask for the obligation to execute a contract, or if it only has the right to claim damages, it is doubtful (Shahbazi, 1392, 77).

\section{4-2- Delay in execution}


Discussing the violation of noncompliance and delay in implementation is different. Certainly, if the damage is determined to delay the execution, the obligee will also be eligible. However, if the damage is received for nonexecution, it is not possible to enforce the other, since the application of the condition is a premature loss for the execution and the procedure that replaces the fulfillment of the commitment that has elapsed, and the summation between the two is not feasible unless That is, the agreement is agreed upon, in which case the name of the violation is not a failure, but a delay in the execution. Sometimes the original contract may consist of several subcontractors. In this case, if the nonperformance of any of the underlying obligations is a condition for the request for damages, the obligated party will, in addition to claiming damages, also have the right to request fulfillment of other obligations and will not suffer any damages (Lotfi, 2007, 64).

\section{5- Determine the law governing the contracts}

Contracts and obligations arising from it are in the majority of legal systems subject to the agreement of the parties to the contract. This law is referred to as the "law of the parties" law.

\subsection{Specific Emirate Determining Competent Law}

If the will of the parties to the contract is not disclosed about the law of jurisdiction, the law governing the contract can be determined in either of the following ways. The first solution is to say that the parties to the contract authority not use the law competent to determine not contract necessarily subject to the law will be predetermined, as "the law of the place of conclusion of the contract" in the contract of carriage or "legal The place of performance of the contract "is deemed to be in force on the contract of employment. Another solution is that the judge, in determining the law of law, preferred the will of the parties and, in the light of the Qur'an and the Emirate, indicating the implicit will of the interlocutors, determine the law of jurisdiction. Between the Qur'an and the UAE, the determination of the law of jurisdiction "the place of concluding and the place of performance of the contract" is the most significant and in fact 
constitute the two poles of the contract (Nikbakht, 2007, 84).

\subsection{Determining the limits of the interlocutor's will}

Although the right of the transferees in determining the law governing the contract is not in doubt, the scope of exercising this discretion is at the heart of the debate. Constituents have such a discretion, according to a free thinker's mindset that is independent of the will. The choice of the law governing the contract is like choosing the other terms of the contract (such as the terms of the contract), and in such a case, the law actually becomes one of the terms of the agreement and is supposed to be merged. This way of thinking has been severely criticized by opponents of the sovereignty of will. The first limitation on the right to choose contributors is the need for a relationship between the law and the agreement, which means that.

Interlocutors should choose a law that is relevant to their contract (Sadeghi Moghaddam, 1391, 62).

\section{Proof of non-execution of contracts}

Reviewing the subject matter of the contracts shows that, in terms of the nature and content of the contractual obligations, they are divided into two categories. Obligations in which they are obliged to provide a definite result that is a commitment to the outcome and obligations that are due to the care that the obligation is due to. Some lawyers have to divide their obligations into verbs and divorces in order to determine who must stabilize the fault. In cases where a commitment to act or to do something like a commitment to transfer the creditor, one must only seek and work It is committed to the reason for paying and doing the work. But in the commitments they are leaving, it's not the case that the committed photographer needs proof of non-performance. But the creditor must prove that he has committed himself to the limits of his duty and has done what he should not do. But this division was encountered in some cases (Katouzian, 2008, 166).

\subsection{Obligations to the result}

When committed is obligated to do something that is determined and the commitment is free from interference by any other factors and the result of the 
obligation is not dependent on any other possibility, it must commit it to a definite result. Such a commitment would commit to the conclusion that In Arabic, it is a commitment to realization. In fact, in such committed commitments, it has committed the existence of the subject of the commitment, and in this case the non-execution implies the fault and even the contractual fault can be assumed. Obviously, he committed the crush by proving that there was a contract containing a commitment

In his favor, he was committed to the outcome and the obligations were not fulfilled (Rezaei Rajaee, 2011, 71).

\subsection{Obligations by means of}

When committed, it is not responsible for the results of its obligations and is not bound by the contract to study a given subject. But the subject of the contract is the ultimate endeavor of applying knowledge to a general commitment to precaution and care, such commitments that are committed to achieving the desired result beyond the power and power of the party and the probability of achieving the desired result is not definitive. And many have not, as a matter of principle, also made such a commitment. In such commitments, according to most lawyers, there has been a violation of the prior standing procedure based on the fact that the failure to fulfill the obligations has not been committed. Whether in the contractual fault, it is assumed that the mere failure to execute the contract is a fault and, once the contract has not been executed, the committed fault is fixed, and the committed pledge does not need to prove the fault (Obiqui, 1391, 49).

\section{The criteria and criteria for the determination of the intentional and unintentional fault committed in the execution of the contract}

In general, the fault is either intentional or unintentional. In the willful misconduct of the subject, the loss, with due regard to his labor punishment, is deliberately intended to violate the result and demand it. Conversely, in the unintentional fault of the subject, the damage occurs without committing the result of the carelessness and so on, causing damage to others. In the opinion of Dr. Katouzian, it is deliberate that the subject is harmed by the intention of harming non- 
perpetrators. Like the one who throws someone in order to take revenge, and on the contrary, it does not intend to harm the other person in the unwittingly guilty cause of the loss, but by accident and unconsciousness causes damage to the non-owner, such as a driver due to accelerated acceleration Driving and causing damage to the road through a collision with another car, in which case his fault is unintentional. The methods of assessing lawyers and prosecutors differ in this regard (Emami, 2008, 102).

In general, the criterion of intentional fault is the personal culprit. But in the unwarranted fault of the criterion, the standard is a standard and a criterion. According to Dr. Katouzian, the prosecution of the intentional fault of the judge has to investigate the intention and the purpose of the error, in order to determine whether he wanted the incident to occur or only Careless.

\subsection{Comparison of the dispute} resolution process in the domestic court and arbitration in execution of the contract

The comparison of the dispute resolution process in the domestic courts and the process of reviewing the arbitration reveals the following distinctions (Shahbazi, 1392, 124):

-The proceedings of the domestic courts do not necessarily have the same nationality as one of the parties to the lawsuit. Also, the lawsuit is usually filed in the country of one of the parties to the contract-importer or exporter-and in the language of the country in question. While arbitration allows third-party litigants to choose their own lawsuits and choose arbitration (or arbitrator's board) with a neutral nationality.

- Judges of the domestic tribunal are required to observe the rules of the forum without flexibility, while the parties involved in the arbitration can choose a flexible way to deal with the suit, according to the requirements of the lawsuit.

- Internal court trials are generally at least in a court of law and at most in two higher trial courts or appellants, some of which prolong the process of prosecution. Conversely, arbitrary judgments are, in principle, ultimate and unexplainable, or appeals. A general feature of the arbitration process is the achievement of a friendly solution. 
- International conventions on arbitration have provided a great deal of power to resolve disputes.

\subsection{Warranties for performance of contractual obligations}

Under the guarantor, the sponsor must be supported and supported so that the law enforcement action against the offender can be demonstrated; in other words, the existence of the right to claim requires the provision of a guarantor for the obligee. Therefore, the right to lodge a claim for the performance of a pledge or payment of damages can be considered from the effects of the right to claim and guarantee its implementation. The guarantee of acts that are rooted in the law, such as "the right to execute the same obligation", can be deduced from $237,238,376,476,534,579$ of the Civil Code. The guarantee is provided by the legislator for the purpose of fulfilling the obligation, and the offender may be the first to guarantee the implementation of the power used to enforce the law or the court order (Kazemnezhad, 2010, 61).

Another guarantee is the right to imprisonment, which, by virtue of Article 371 of the Commercial Code, and
Article 377 of the Civil Code, can be used in all arbitrary agreements such as betraying and marrying, and as long as it has not fulfilled its obligation, the debtor may also Do not commit to its commitment. In addition to these, it is possible to include, among other things, the performance guarantee in the Root Act to invalidate, not to affect the transaction, or to compensate for losses in waste and cessation;

One of the guarantors of the contract is the "obligation" clause contained in the contract, in which case, in commercial contracts, the conditional condition is one of the safeguards of the contractual advances of the contract of engagement, in which case, usually in commercial contracts, a condition is included in which, if One of the interlocutors to refuse to execute what the contract entrusts to him or to engage in any act that is prohibited by the contract, must pay the amount specified in the contract as damages to the opposite party (Bahrami, 2007, 73) .

\section{Types of compensation for breach of contractual obligations in English law}

In England, four types (or models) of compensation for damage 
from contractual obligations are foreseen. These four types can be divided into two main groups: in the first group, there are cases where the compensation criterion is the actual loss of the lost, and in the second group the compensation criterion is not a loss to the loser. Compensatory or remedial damages in the first group and reparative, nomual and punitive damages fall into the second group (Lotfi, 2007, 106).

\subsection{Compensatory or Restorative Damage}

The purpose of the compensatory or remedial damages is to compensate the loss sustained by the breach of contract. For this reason, compensatory damages are the most important and most common form of suffering. Thus, the remedial damage is the general rule and the basis for compensation in the UK. One of the results of the remedial damage is that the basis for the loss, the loss of the requester It is not the benefit that the reader has received. This rule has many exceptions:

Regardless of damages that have non-recovery goals (nominal, punitive, and restitution damages), UK legal writers also mention other cases in which they do not require damages, such as breach of employment contract (Treitel, 2003, 927 ) In such a case, an employee may not be inaccurate in practice by employing a better institution, and on the other hand, his employer has not effectively countered this breach. In such a case, the damage that may be received will not be in the subset of any of the types described. To assess the remedial damage in UK law, there are two anticipated damages and repossession damages. Along with these two criteria, the special status of the spiritual damage should be considered in terms of how to assess the damage to the repair.

\subsection{Expected Damage}

The intended damage is as expected and expected, which has created a contract for the present (current loss); in other words, in this type of warrant, a judgment is issued for some amount of compensation that meets the legitimate expectations if The contractual obligations were fully and timely. In fact, anticipated damages have a basis for compensating for noncontractual obligations (Stone, 2003, 
211). As the purpose of non-contractual liability is to put the lost person in a situation where the harmful act is not performed, the purpose of this type of remedial damage is to put the lost person in a situation where, if the contract was executed, the lost person was placed in that position. The most common type of repair damages is expected to be damaged. Expected damages include, in the first place, the damaged principle; but it also includes other items that include:

Extraneous damages; including losses incurred by the person at the usual level, in order to prevent further losses, or to spend the replacement or return of the defective product (Treitel, 2003, 43).

Indirect or intermediate damages are damages caused by breach of contract, but cannot be placed in a group of costs (reimbursement losses); disadvantages and such as acceptance of obligations with third parties or additional damages, such as injuries Physical or property damage is due to the defective goods delivered in this category. Of course, these damages can be compensated if they are within the scope of anticipation and expected expectations of the parties to the contract, that is, it is not very unlikely;
372

for example, suppose a person will sell a cow with a guarantee of its health, but the cow becomes ill and the entire herd of the buyer is also ill. If the seller is responsible for any damage to the customer, if such an outcome is foreseen for the parties to the contract, the seller will be liable for all losses incurred by the customer (Scotia Building, 1391, 59).

For example, if someone has a device that needs to be repaired and to do this, he will give the device for repair to someone else and ask him to deliver it on a particular day, because if he does not, he will be harmful if he The repair technician will not deliver the device on time; he must pay for the losses caused by the loss of his interests, because if he fulfilled his commitment, he would have benefited. Two methods are used to calculate the expected loss:

In the first method, which is used more often in defective or incomplete implementation that has a minor utility, the difference in value between the execution of the contract agreed upon and the performance received by the sponsor will be ruled out as a lump sum.

A second method is used where the obligation is not implemented or the performance is in some way defective or 
incomplete, which does not have any desirability for the undersigned. In this case, the amount of compensation is paid to the claimant, which is necessary to obtain alternative implementation.

\section{-3. Reposing damage}

In repossessment, the injured person will be compensated for the damage caused by his dependence and trust in the contract; in fact, in the contract, he may wish to change his position with confidence in his obligation. For example, a piece of land may incur costs to the buyer for the investigation and examination of the claimant (costs related to the inquiries) or to ignore his opportunities to conclude other profitable ones; or to trade for contracts that may have been borrowed by the contractor Or has created facilities; therefore, in the event of a breach of contract, the reader must compensate for such losses, which are due to his dependence and trust in his obligations (Emami, 1387, 157).

The purpose of this type of remedial damage is to place the lost person in a situation that was before the conclusion of the contract and reliance on the obligations of the other party. In the sense of the law of obligations, reparation losses are interests that are lost due to reliance on the obligations of the defendant and must restore the injured party as if it had not been contracted (Geoffrey, 2001, 204).

The question to be answered at this stage is what are the components of repossession damage, and what costs and losses can be obtained with this criterion? The reciprocal damage consists of three parts. The first part is the expenses that the vendor incurred after the conclusion of the contract with the trust of the commitment; this is unquestionably achievable.

The second part is the costs incurred by the entity prior to the conclusion of the contract; such costs are not in the strict sense of reliance, since at the time of this cost, there was still no commitment. However, the UK legal system applies a broad concept of reliance on this criterion, so that if a claim for compensation for a breach of contract with a reinstatement clause is raised, then sure sure that pre-contractual damages arising from reliance are permissible. This case was reviewed and confirmed in the case of the Angola TV case against Mr. Reid. 
The case came from a television company, which in 1968 decided to produce a television movie called "Forest Man." To make this film, the company provided the necessary preparations; it provided a place for the film; the director, the designer and the director of the scene were hired and paid a lot of money. All of this was before they were hired as a first-rate art. Mr. Robert Reid was the one who was chosen for this role. In a telephone conversation on Aug. 30, 1968, Mr. Reed, an American, agreed with his agent to go to England to practice and play the film, but due to inappropriate planning, it became clear that he had previously played in another role in the United States The contract is closed and so could not go to England. This stopped filming and dismissed those who were hired, causing a lot of damage to the television company, including the director's fee, designer, stage director and scene assistant. During a lawsuit filed by the television company, Mr. Reed's consultant stated that the other party was only entitled to the costs incurred after the conclusion of the contract with Mr. Reid, not the right to receive pre-contract costs (pre-contract costs ) But the judge dismissed the controversy and condemned Mr. Reed to pay all the damages. The third component of the damage is the loss of opportunity to conclude other contracts. There is much disagreement about retrieving this component. At present, a broad concept of reliance is accepted by scholars who include this component (Geoffrey, 2001,199).

In choosing either of the two claims for damages and repossessed damages, the claimant has the right to choose; however, in some cases the court may find that a certain rule is more appropriate. The question now is, when is the lender willing to lodge a claim for retaliatory losses? In response, one can imagine two situations (Amir Ma'azi, 1391, 67):

First, in the event that he fails to prove his probable profit from the execution of the contract or the expected loss. A good example of this case is a highly probable deal. Or transactions that are not based on the possibility of determining the expected damage.

Secondly, where losses (liabilities) are to be incurred, they should be concerned with precontractual costs. Although, in principle, there is a choice between the expected and reimbursable losses, but in certain 
circumstances it is possible to claim both damages without leading to "compensation" There will be "double". This rule has been confirmed in the Natoon case against Aklan. The case was about a horse which was not delivered in accordance with the agreed terms; the buyer received reliance on the difference between the value of two horses as expected losses and the cost of training and stables as damages. Of course, this should be noted. If, in the calculation of expected loss, the net profit is claimed, then it can be accompanied with a claim for repossession and summing up these two, but if it is to be considered in calculating the expected loss in gross profit, then it can not be claimed to be liable to the reimbursement of benefits Also posed (Stone, 2002, 46).

Famous Chaplin lawsuits against Hicks in 1911 and Eid Ramsey Lutte Group against Simmons and Wimmons in 1995 cited important lawsuits regarding the terms, components and enforcement of damages in reimbursement for breach of contract.

\subsection{Intangible or spiritual damages}

375

The point at which the compensatory damages should be addressed at the end of the discussion is whether non-financial damages caused by a breach of obligations can also be recovered and compensated. First, there must be a difference between the two types of losses: physical immaterial losses and non-physical Damages Compensatory losses, such as distress and distress caused by contract breaches. There is a clear legal rule that damages for physical damage to the claimant as a result of a breach of contract can be obtained; this rule was approved in the Grant v. Australia judgment against the Australian Knitting Mills Limited Liability Company. In this case, Dr. Grant became infected by the wearing of wool belts produced by the Australian Nitting Mills. The dress involved contained a lot of sulfite. Dr. Grant used the podium for a full week without having to wear it before. The Royal Council issued a sentencing sentence to compensate for physical harm.

But the problem is in cases in which they are suffering from distress and sadness as a result of violations of obligations. The Court of Appeals in the Watts v. Marv case decided that the damage to the contract for such non- 
financial losses would be unwarranted. But Judge Bingham points out in this case that this is not an absolute rule, and the exception is that the main subject of the contract is to provide recreation and comfort, or to be released from a sadness, and this result (the subject of the contract) has not been obtained or the result is inverse Get it. In these cases, a judgment has been issued to compensate for such damages. Another proof of nonfinancial non-financial damage is the case of Farley against Skinner. In this case, the petitioner recruited Droid as an assessor and evaluator to review the utility of a bungalow intended to be offered for rest during their weekends (Babaei, 2007, 54).

Given that the property was located 15 miles from the airport of Gittivac, you wanted to explicitly ask the DROID to report on the problem of airborne sound. Droid did this and reported that it is unlikely that the sound will be used to optimally use the intrusive location, although some planes will inevitably cross the area due to wind direction and flight path. After acquiring more than $£ 1,000$ for repairs, he realized that the sound of planes made him a homeowner for the benefit of his own; therefore, he filed a lawsuit for damages
376

against the defendant, claiming that the defendant had complied with his obligations under The contract has been neglected. The court sentenced a 10,000pound damage claimant to the trouble and distress caused by the sound of planes. The appealed to the appeals court argued that the subject of the contract between the parties was not to provide pleasure or to relieve stress, so nonfinancial damage could not be received. And only the nominal damages for breach of contract are payable. Finally, the House of Lords, by violating the verdict of the Appeals Court, accepted the right to non-physical non-financial damage (Isanlou, 2011, p. 99).

\subsection{Damage to recovery or rescission}

In this type of damages, the lender will reimburse any profits earned for breach of obligations. The basis for damages is the prevention of unjust liability, but not the damage actually committed to the obligated party. The importance of the place of litigation based on extradition damage can be demonstrated with a good example (Hossein Ebadi, 2011, 104):

$$
\text { Suppose someone signs a }
$$
contract, whereby he pays 500 pounds 
for a product with a real value of 300 pounds. In such cases, if he wants to file a lawsuit based on his own interests, he will only reach 300 pounds. If you file a claim for extradition benefits, you will receive 500 pounds (Mckendrick, 2005, p. 162).

This is where the person claims that the type of damages usually involves a contractor, and, contrary to the two preceding paragraphs, the basis for assessing the damage is not the loss incurred to the obligated party, but the gain that he has undertaken to breach the contract. For this reason, some writers do not consider restitution damages as a liability assessment criterion (Jaffey, 2008, 139).

At first, it was assumed that the payable Thanh can be refunded as an extraditable damage, which is a total violation of the obligation, that is, where the claimant did not receive any part of the execution. But many academic commentators criticized the law (Mckendrick, 1995, 280), and today most lawyers believe that paid money must be received on the basis of a breach of obligation, whether it is a breach of the general obligation or part (Mulcahy, 2008, 218).
It is a very common use of damage damages which, as well as the failure of other types of damage in English law and ineffective in defining the extent of compensation in Iranian law, is a violation of intellectual property contracts. In these contracts, the contract may not be entered into with the other party in breach of the practice, or the violator can earn more revenue from the violation of the contract than the creditor, thus, in practice, the loss was not sought by the claimant, but the defendant was entitled to a breach of profit has taken. For example, someone who uses misleading business secrets or confidential information is likely to be transferred to the redundant by the court order (Sadeghi Moghaddam, 1391, 66).

In England, extradition damage also has other instances that seem to be specific to the legal system, for example, if the subject of the land contract is the seller, after the conclusion of the contract, as the real buyer of land, andIn England, extradition damage also has other instances that seem to be specific to the legal system, for example, if the subject of the land contract is the seller, after the conclusion of the contract, as the real buyer, holds the land and if the land is back to A third party sells, the 
buyer will be entitled to the sales revenue, even if it is higher than the loss. The other is a breach of the obligatory obligations; for example, he sells his property to genuine, such as where he is hired for the purchase of property; in this case, the agent must give all the gains he has gifted to genuine (Treitel, 2003, 97).

\section{8-6. Nominal Damage}

In cases where one of the parties has violated the contract, but in practice, the damage has not been noticed by the opposite party, a very small amount will be determined symbolically as damage and will be ruled out. Determining this kind of damage is not to compensate for the loss of the loser, but to reflect the breach of the contract.

And it has a symbolic aspect. In symbolic damages, this statement is the most appropriate remedial way. Undoubtedly, this remedy does not have a remedy (Treitel, 2003, 27). In Iranian law, contrary to British law, there are no institutions such as nominal or symbolic damages, based on the principles of compensation. Therefore, the violation of the contract by the obligated party will not create the right to receive damages without entering the damage to the obligated; hence, the "necessity of entry of losses" is one of the conditions for the establishment of the right to receive damages in the Iranian law (Katouzian, 2008, 210).

\section{8-7. Punitive or Punitive Damage}

Punitive damages have no restorative effect and are issued for punishment and preventing the same behavior being committed in the future (Fleming, 1985, p. 131). In fact, the punitive damages issue arises where it undertakes a courageous and unconventional contravention of the contract. This kind of damage is exceptional in terms of the overall recovery of damage (Geoffrey, 2001, 204). In calculating this kind of damages, the behavior of the reader and the one who wants to be considered simultaneously should be considered. And in particular, note that determining how much damage will suffice to punish the donor "(Abdullahi, 2004, 93).

In the Bradford case against Aurora in the year of the appeal court, in addition to the actual damage sustained, including moral damage, the decision was made to receive $£ 1,000$ on punitive damages. The court declared the reason 
for such punitive damages to be breached by the employer because of a breach of employment contract based on gender and race discrimination. There is a controversy among the experts about the existence or absence of such damage in the event of contravention of contractual obligations in the UK legal system, often arising from the mixing of civil and civil rights obligations. However, given that these damages do not have a compensatory and restorative nature, we do not enter details of the punitive damages.

It appears that Iran's law does not provide for such damage in contravention of contractual obligations, but on an obligation that the parties agree on the amount of damages resulting from the breach of contract, if the damage is significantly higher than the damage that was committed before It is anticipated that a breach of the contract will result. Such a lien will lose its compensatory aspect and will be more punitive. For example, a person signs a contract for painting his home for 10 units of value and stipulates that if any delays occur, he must pay 1 million dollars per day. Hence, a number of lawyers believe that such obligations that are more criminalized can be adjusted (Katowice,
2008 , p. 270). It can be deduced from the punitive and punitive aspect of clause 2 of Article 4 of the Civil Liability Law that these provisions provide for the guarantee of the breach of contract (Katouzian, 1385, 209).

\section{Limitations on Claims for Damage in English Law}

The injured person can not be damaged in any circumstances because the rights have created a variety of restrictions on this. These limitations are sometimes inherent and occasionally related to the usual rules of proof, for example, the claimant must prove that he has violated the provisions of the contract and .... In this section, based on the rights of the United Kingdom, four theories, each of which One of the limitations of claim claims is to be considered.

\section{9-1. Unlikely}

According to a rule, a claimant can not claim damages in relation to the harm caused by the breach of contract by the reader. In fact, it can be said that the damage must be attributable to the obligation (Stone, 2003, 102). Detecting 
losses that are very unlikely to be unrecoverable is often difficult to obtain from the loss. The rule that was set up by Kessendal was that in the case of Hadley against Case B, it would be possible to receive two damages: the losses inherent in breach of contract. There were losses in the minds of both parties at the time of the contract (awareness).

Awareness of the parties to the contract is the result of the violation of the contract, which is the criterion of identifying whether it is unlikely or not, at the time of the conclusion of the owner's contract, because, knowing such results at the time of the conclusion of the contract, the parties may mutually agree on the terms of their contract. For example, make a non-liability condition or insure possible risks, or generally abandon the conclusion of such a contract (Stone, 2002, 47).

\subsection{Discount theory}

According to this theory, the claimant must take rational and reasonable steps to minimize the damage caused by the violation of the prediction. For example, in cases where a rational consumer can choose to run an alternative on the market, he must go to the market and seize it; he cannot sit and wait for the donor to execute the contract. It is said that the claimant has the duty to discount or reduce his losses, but these words can be misleading; in fact, the claimant has the duty to reduce his losses. In the sense that in case of failing to do so, he will not be able to obtain damages in respect of losses attributable to him. Two aspects are mentioned for the discount theory:

The claimant shall not unreasonably increase the damage sustained as a result of the breach of contract. The claimant must, in a rational manner, anticipate the necessary steps to reduce the damage. Of course, he needs to behave only intellectually; therefore, he does not create a heavy and painful demand for him; in fact, the reader as a violator of the contract is not in a situation where the court requests a heavy and laborious demand from the petitioner. Slowly Of course, the task of reducing damage is limited to the extent that he is aware of the breach of contract. As a result, his indiscriminate dedication to discovering a breach of obligations can not invalidate his right to receive documentary damages for failure to perform his duty of reduction of damages (Treitel, 2003, 77). 
Discounted theory As Judge Tomlinson has said, he has a soft-minded view of the rights of contracts than those who contravene the contract.

This theory can justify the need for the innocent side and the likelihood of accepting the need for alternative enforcement by the offender; in one of the famous cases in this regard, the readers agreed to a contract to sell silk to the buyers and deliver the goods to The installment is multi-stage. In the contract, it was stipulated that the payment should be made one month after the delivery of each major part. The applicants failed to pay the first installment at due time; this made the readers mistakenly to conclude that the claimants were not able to pay any installments (while the reason for delaying payment was merely the difficulty in getting a check of the signature Was made by one of the managers of the requesters).

Due to fears of bankruptcy, the complainants stated in announcements that they would not make any further deliveries unless they paid for each installment at the time of delivery. Applicants did not accept such a condition. They sought to claim damages and sought to find a difference in price between the contract price and the price of the silk market (at that time, the price of the goods in the market was increasing). The court ruled that the claimants were not entitled to receive price differentials because they refused to accept the offer made by the reader for providing silk against cash, and this was a kind of failure to discount losses. The judge of the case stated that in a case involving a commercial contract, it is reasonable for one of the parties to expect to consider and accept the logical proposal provided by the infringing party. The last point to be noted with regard to the theory of discounts in English law is that this theory can be considered as part of the broader principle that "the petitioner must behave in the ordinary way." Lord Lloyd admitted in Roxley's case that the conventionality would be limited to the theory. Rather, a commitment to normal behavior can extend to issues such as the compensation criterion that it deserves (Mckendrick, 2005, 111).

Although the Iranian legislator has not explicitly recognized the theory of discounts as a rule that has been accepted in other legal systems especially those with a common system of law, - there are signs of acceptance of 
this theory in Iran's law and based on it Compensated liability of the offender for compensation. Including:

Article 15 of the Insurance Law approved in 1316: "An insurer shall also take insurance to prevent any damage to property caused by anyone, and in the event of an accident or occurrence of such incident, the insurer shall take measures to prevent the occurrence and development of damage It is necessary to do. The first time possible and within five days from the date of its notification of the incident, the insurer shall be informed otherwise the insurer will not be liable unless the insurer proves that he has been informed by events beyond his control. The insurer has not been possible for him within the time allowed. The expenses incurred by the insurer in preventing the spread of damage will be borne by the insurer, assuming that it will not have a result, but whenever there is a difference between the parties as to the necessity of such expenses or its appropriateness to the insurance issue, the resolution of the dispute to The verdict or court is referred to in "Section 3 of the Civil Law Act of 1339": The court may reduce the amount of damages in the following cases: ... 3. When the injured person in some way facilitates the loss, or That assistance or import situation has exacerbated the losses. "

Community3.

Lost

Participation in Damage (Damage Damage)

The main question of this section is whether it is possible to reduce the amount of damages payable to the petitioner based on his lack of care.

In England, according to the 1945 law, there is a well-established rule that, in non-contractual liability, it is possible to reduce the damage that can be received from the injured party by default. The question is whether this rule applies to contractual obligations or not? The House of Lords of England, according to the aforementioned law in the case of the Federal Anti-Doping Code, Vesta against Boucher Vesta against Boucher, regarding the applicability of this rule in the responsibilities of breach of contract, distinguishes between the three different situations and determines the ruling of each assumption.

The liability is due to a breach of a contractual obligation that does not depend on the fault of the underlying supervision; in other words, the breach is merely a contractual nature and a breach of a purely contractual obligation, and if 
there is no contract, it cannot be considered a fault. In this case, the reader may not invoke the loss incurred in order to reduce his liability to the lost participant. This rule was confirmed in the Barclays Bank PLC v. Kirkhl Bilding Limited Company (Kazemnezhad, 2010, 46).

The prosecution is due to a breach of an express contractual obligation with regard to the exercise of standard care, which has nothing to do with an obligation that is independent of the contract; in other words, if it was not a contract, this was not a public duty to him. In this assumption, the reader can not rely on the loss incurred by the loss participant to reduce his liability. The liability arising from the breach of contract is the same as the noncontractual liability, so that if the contract was not available, the defendant was deemed responsible for his noncontractual liability; in other words, his action independent of the contract was also a fault. Under this assumption, the loss-making contribution to the loss incurred can be cited as a defense to reduce the scope of the liability of the defendant. The Verdict of the House of Lords in the case of the Limited Liability Company Ltd The Homes Lones
Platform v. Oyston Shiplois and others are an example of this rule.

In Iranian law, defective damages cannot be taken as an impediment to the creation of a right to damages, but as a possible limitation in obtaining the full amount of damages (compensation for damage). According to Article 227 of the Criminal Code: "A violation of the obligation is damaged when it is convicted of damages that cannot prove that non-fulfillment was due to an external cause that can not be related to it". According to this article, the failure to execute the contract itself is an act committed on the fault, so he must prove that the contract has not been fulfilled due to a cause beyond his control (Katozian, 2008, 159).

\section{Result}

The topic of great interest in all three types of contract liens in common law is its common characteristics. It can be said that the sudden occurrence of an out-of-domicile event is the chapter of the implicit contractual theory, that is, in all three cases, there should be a sudden occurrence outside of domination. But Harry's ducts are characterized by three different theories and the width of each 
of the types of invaluable by the extent to which they have an impact on the contractual obligations.

All legal systems seek full compensation; in this regard, due to the existence of a remedial remedy for damages among other compensatory remedies in the United Kingdom, the country's legal system has determined precisely that the determination of total damage based on them is more regular and more precise The loss of evaluation criteria, such as expected damage, retention and recovery with specific components and subsets, and the precise determination of the barriers and conditions for claiming damages, is part of this regular structure. On the contrary, Iran's rights in dealing with the issue of damage have been totally complicated; the Iranian legislator has not only not explicitly determined the types of damages to be compensated, but even in the cases provided, it does not provide the criteria for the assessment of damage; However, it is as if the legislator did not consider the principle of the existence of compensation for damages in contravention of contractual obligations.

To reform the status quo and synchronize it with the evolution of different legal systems Facing the problem of compensatory breach of the obligation, the Iranian legislator can, by exploiting the comparative rights achievements in the field of contractual rights, create a comprehensive system of damages for breach of contractual obligations. In order to achieve this, in the first place, it is necessary to specify the types of compensable damages in Iran's law, and the legislator will declare his or her definitive opinion on certain matters, such as lack of benefit, spiritual damage, etc. In the second step, the criteria and criteria for the assessment of damage should be provided, because on the one hand, the Iranian judge in the assessment of damage should not be in the legal sense of such a proprietor and owner as to fall as an expert, and on the other hand, should not limit the extent of the damage assessment to the contractual violation It is so disappointing that it is unpredictable and therefore cannot be eliminated, or covered by tools such as insurance.

Ethics, public order, and laws are among the factors controlling the condition of non-liability. The British law has emphasized on the need to address the addressee in dealing with these conditions and, by adopting specific consumer laws, supports the 
courts, and, moreover, the courts of this The country has also prevented imposition of unfair terms by relying on rules such as the interpretation of ambiguities against the citation. If he or she has not committed intentional or faultless mistakes, the acceptance of the lawsuit will give rise to conflict and waste of time and a reduction in the value of the inclusion of the condition of nonresponsibility, since one of the important effects of the condition of nonresponsibility is to close the quarrels in vain and give the opportunity of initiative and It is an activity that should not be considered as a liability for intentional misconduct when committed intentionally or in deed intentionally.

\section{References}

\section{A) Persian Resources}

AMI MAZI, AHMAD. (1391). Rules for

Resolving Disputes in the Law Governing Contract Obligations, Printable Version, Tehran, Judicial Publishing Institute.

Emami, Seyed Hassan (1387). Civil Rights, Vol. I, Twenty-eighth Edition, Tehran, Islamiyah Publications.
385

Isanlou, Dr. Mohsen. (1390). Contractual and Imperative Terms of Contracts, Printable Version, Tehran, Public Joint Stock Company.

Construction of Scoie, Majid. (1391). Qualitative dissolution and arbitrarily contracted contract, Journal of Two Civil Law Knowledge Research Papers, Payame Noor University.

Babaei, Iraj (1386). Theoretical Foundations of Economic Law Analysis, Journal of Law and Policy Research, No. 23.

Bahrami, Mohammad (2007). The analysis of the contract and its essential elements in civil law, Quarterly Legal Opinion, No. 8.

Hossein Abadi, Amir. (1388). "Investigating the Compensation Obligations in the Contract", Journal of Legal Teachings, No. 14.

Rezaei Rajaini, Allah. (1390). Implementation of Civil Covenants, Fourth Edition, Tehran, Eternal Publishing. 


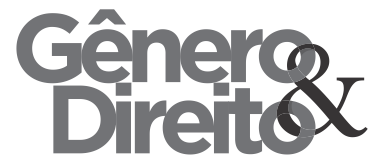

Periódico do Núcleo de Estudos e Pesquisas sobre Gênero e Direito

Centro de Ciências Jurídicas - Universidade Federal da Paraíba

V. 8 - No 03 - Ano 2019

ISSN | 2179-7137 | http://periodicos.ufpb.br/ojs2/index.php/ged/index
Shahbazi, Mohammad Hussein. (1392).

Principles of Necessity and Permissions for Legal Enforcement, First Edition, Tehran, Farzanegan Dad Afrin Institute for Legal Studies.

Sadeghi Moghadam, Mohammad Hussein. (1391). The theory of changing circumstances in Iran's jurisprudence and law, Quarterly Legal Opinions, No. 14.

Abdollahi, Mohsen (2004). Punitive Damage in International Law, Legal Magazine- Journal of the International Legal Services Office of the Islamic Republic of Iran. No. 30

Katouzian, Nasser (1387). General Rules of Contracts, Volume Four, Fifth Edition, Tehran, Publishing.

Kazemnejad, Naser (1389). Contract modification, master's degree of Law School, Shahid Beheshti University.

Lotfi, Asadollah. (1386). Study of the Principle of Necessity in Islamic Contracts, First Edition, Hamedan, Student Publications.
Nikbakht, Hamid Reza (2007). How to determine the law governing contractual obligations, Quarterly Journal of Legal Research, No. 21-22.

\section{B) Non-Persian sources}

Fuller, Lon L. \& Perdue. William R. (1999). The Reliance . Interest in Contract Damages. 46 Yale Law Journal 52.

Honnold, John, 1991, p393, Uniform law for international sale, 2nd, Denever, Kluwer law and Taxation pub.

Geoffrey, Samuel. (2001). Law of Obligations and Legal. Remedies. Second edition Cavendish Publishing Limited.

Jaffey, Peter. (2008). Damages and Protection of Contractual Reliance. in Contract Damages- Domestic and International Perspectives. Saidov Djakhongir and Cunnington. Ralph (eds). Hart Publishing.

Mckendrick, Ewan. (2005). Contract Law (Text, Cases and Materials). Second edition Oxford University Press. 
Stone, Richard. (2003). Contract Law (Q

\& A Series). 5th edition. Cavendish

Publishing Limited.

Smith, J.C., law of contract. (1989),

London, sweet and, axwell

Treitel, Guenter. (2003). The Law of

Contract. 11th .Edition. London: Sweet

\& Maxwell 